\title{
NATURAL HISTORY AND BIOGEOGRAPHY OF THE AMPHIBIANS AND REPTILES OF KIBALE NATIONAL PARK, UGANDA
}

James Vonesh

Department of Zoology, University of Florida, Gainesville, FL 32611

English Abstract. This study lists the amphibian and reptile species of Kibale National Park, Uganda, and discusses the natural history and biogeography of this unique herpetofauna. This herpetofaunal inventory was compiled based upon literature records and collections made during 17 mo fieldwork between 1995 and 1997, and includes 28 anuran, 15 lizard, and 32 snake species. Faunal comparisons with seven other tropical African forests show a high degree similarity between the Kibale herpetofauna and those of central and West Africa.

French Abstract. Cette étude se propose d'une part, de dresser une liste des amphibiens et des reptiles du Parc National de Kibale, en Ouganda, et d'autre part, d'éclairer l'histoire naturelle et la biogéographie de cette unique faune erpétologique. Cet inventaire des espèces reptiliennes repose sur des dossiers et collections recueillis pendant dix-sept mois de recherches dans les années 19951997. Il comprend vingt-huit amphibiens anoures, quinze lézards et trente-deux espèces de serpents. Une comparaison de la faune de sept autres forêts tropicales africaines indique que l'erpétologie de Kibale s'apparente à celles de l'Afrique centrale et de l'Afrique de l'Ouest.

Africa's tropical moist forests extend from Senegal, West Africa, to the montane forests of eastern Somalia (Collins, 1992) and are home to an estimated 333 amphibian species (Duellman, 1993), 105 snake species (Hughes, 1983), 95 lizard species, 16 turtle species, and three crocodilian species (Bauer, 1993). While these estimates illustrate the richness of the African rain forest herpetofaunas, our knowledge of these faunas is far from complete. Furthermore, the forests of Africa, like those worldwide, are disappearing at an alarming rate. Deforestation in West Africa is particularly severe, averaging $90 \%$ loss of the original forest cover from Sierra Leone to Nigeria. The forest of central Africa is also threatened from all directions, with an estimated $57 \%$ of the 
forest of central Congo lost already (World Resources Institute, 1994). Other regions of central and East Africa are experiencing similar loss. For example, an estimated $86 \%$ of original forest cover has been lost in Uganda (World Resources Institute, 1994), and the remaining forests are primarily isolated fragments, which are vulnerable to encroachment and exploitation by a rapidly expanding, predominantly rural population. These threats may limit our opportunities to study the flora and faunas of the remaining East Africa forests. Relative to other vertebrate groups, amphibians and reptiles in East Africa have been poorly studied. The need for baseline herpetological research in tropical Africa has been pointed out by a number of authors (e.g., Mittermeier et. al., 1992; Lawson, 1993; Drewes, 1997), who discussed the difficulty in conserving faunas we know little about.

The forests of East Africa are generally thought to consist of two nonoverlapping herpetofaunas (Schiøtz, 1976). The first fauna is regarded as an eastern extension of the Congo forest block stretching from Cameroon to western Kenya. The second is that of the Eastern Arc Mountains and the East African coastal forests. Howell (1993) reviewed the Eastern Arc fauna fairly recently, but few studies have examined the herpetofaunas of the Congolean block associated forests in East Africa since Loveridge (1935, 1942a, 1942b, 1957). These include the Budongo, Bwamba, Kibale, Bwindi, Mbira, and Mt. Elgon forests in Uganda and Kakamega Forest of Kenya. Of these forests, only the herpetofauna of Bwindi in southwestern Uganda has been inventoried (Drewes and Vindum, 1991, 1997).

Kibale National Park in western Uganda is one of the most thoroughly studied forests in East Africa. Research at Kibale in the last three decades has resulted in approximately 160 scientific publications. While most research in Kibale has focused on primates, a number of studies have focused on other taxa, including fishes, birds, rodents, ungulates, and elephants. Amphibians and reptiles have received little attention and are the only vertebrate groups for which there are no Kibale species lists. Herpetological collecting in Kibale has been limited. Arthur Loveridge collected 8 species of amphibians during a $10 \mathrm{~d}$ visit to Kibale in 1938 (Loveridge, 1942c), Pitman (1974) includes records for 15 snake species from Kibale, and Schiøtz (1975) collected 6 hyperoliid frog species from Kibale. Thus, 14 frog and 15 snake species were known from Kibale prior to this study.

This study provides an overview of the amphibian and reptile diversity and natural history of Kibale National Park based upon the results of a survey conducted between 1995 and 1997. I also compare the herpetofaunas from eight tropical African sites, in order to examine the distribution of tropical forest amphibians and reptiles in the context of forest refugia theory.

\section{METHODS}

Study Site

Kibale National Park is located in western Uganda between lat $0^{\circ} 13^{\prime} \mathrm{N}$ and $0^{\circ} 41^{\prime} \mathrm{N}$ and 
between long $30^{\circ} 19^{\prime} \mathrm{E}$ and $30^{\circ} 32^{\prime} \mathrm{E}$ near the eastern base of the Ruwenzori Mountains (Figure 1). Kibale was established as a national park in 1993; prior to that it was managed as a forest reserve with selective timber extraction and a number of exotic softwood plantations. Currently, approximately $766 \mathrm{~km}^{2}$ are protected. The park is characterized as primarily a moist evergreen forest, transitional between lowland rain forest and montane rain forest (Struhsaker, 1997; Skorupa, 1988), but a variety of habitats including swamp, grassland, woodland thicket, and colonizing scrub are also represented (Struhsaker, 1997). Rainfall is typically concentrated during two distinct wet seasons, March through May and September through November. The mean annual maximum temperature measured at Kanyawara is $23.3^{\circ} \mathrm{C}$, and mean annual minimum temperature is $16.2^{\circ} \mathrm{C}$ (Struhsaker, 1997). The flora, fauna, and management and research history of Kibale have recently been reviewed (Struhsaker, 1997).

Six sites in or adjacent to Kibale were sampled for amphibians and reptiles in this study; Lake Nyabikere, Kanyawara, Dura River near Kanyanchu, Mainaro, Sebatoli, and Ngogo. The Sebatoli and Mainaro sites are approximately $10-15 \mathrm{~km}$ apart along a northsouth gradient, while Ngogo is $12 \mathrm{~km}$ southeast of Kanyawara (Figure 1).

Lake Nyabikere (Figure 2) is a crater lake outside the park surrounded by agriculture and a few small forest patches. This site represents typical "farmbush" habitat outside the park and was sampled on 12-13 January 1997.

Kanyawara is the site of the Makerere University Biological Field Station and the area of most intensive sampling. It is situated at an elevation of $1500 \mathrm{~m}$ and is characterized by the steepest terrain, with an average slope of $8.7^{\circ}$ (Chapman et al., 1997). The most abundant tree species are Uvariopsis congensis, Markhamia platycalyx, and Bosqueia phoberos. Large emergent trees include Parinari excelsa and Pseudospondias microcarpa, which reach heights of $30 \mathrm{~m}$ (Chapman et al., 1997). Rainfall at this site averages approximately $1600 \mathrm{~mm}$ per year. Aquatic amphibian breeding habitat surveys focused on four Kanyawara sites: Lower Camp Well, a permanent artificial pool approximately $15 \times 14 \mathrm{~m}$ on the forest edge in a swamp forest patch (Figure 3); K30 Forest Pool, a shallow natural pond approximately $20 \mathrm{~m}$ in diameter along the Nykagera stream in unlogged mature forest (Figure 4); Mikana stream and seasonal flooded swamp forest (Figure 5); and Karumbi Road ephemeral pools, tire ruts on an old logging road that seasonally fill with water (Figure 6). Forest leaf-litter sampling was also concentrated at Kanyawara, with 100-140 plots measuring $25 \mathrm{~m}^{2}$ in each of 3 types of areas: unlogged forest (Figure 7), selectively logged forest (Figure 8), and exotic pine plantation (igure 9 ).

The Dura River site near the Kanyanchu tourist center was the second most intensively sampled area. This riparian forest at 1250 m elevation along the Dura River is characterized by the lowest relief (mean slope $5.9^{\circ}$ ) and is dominated by the trees Celtis durandii, Uvariopsis congensis, and Bequaertiodendron oblanceolatum (Chapman et al., 1997). Several habitats were sampled at Dura River (Figure 10), including 8 leaf litter plots of $25 \mathrm{~m}^{2}$ on the north bank of the river; dip net sampling of seasonal pools along the river; and visual searches of several stream tributaries of the Dura River and a 
grassy forest gap (the elephant wallow) at the Kanyanchu tourist center (Figure 11). Approximately $14 \mathrm{~d}$ were spent sampling at this site during 1996-1997.

Mainaro, the lowest site at $1200 \mathrm{~m}$, is characterized by Cynometra alexandri forest (Figure 12) along the Dura River (Chapman et al., 1997). Here, the river seasonally inundates adjacent forest, forming pools that become isolated from the river. Three collecting trips were made to this site during July-August 1997.

Sebatoli, at an elevation of approximately $1600 \mathrm{~m}$ (Struhsaker, 1997), is characterized by riparian forest along the Mpanga River (Figure 13). During heavy rains the forest is inundated. Three collecting trips were made to this site during 13-15January 1997.

The Ngogo field station, at an elevation of $1350 \mathrm{~m}$ (Chapman et al., 1997) was visited during 3-5 December 1997. Nocturnal and diurnal searches were conducted along the Kanyanchu stream and surrounding forest. Ngogo receives less rain than Kanyawara, approximately $1490 \mathrm{~mm}$ per year. The forest is characterized by moderate topographical relief (mean slope $6.0^{\circ}$ ) and is dominated by three species (Figure 14): Uvariopsis congensis, Diospyros abyssinica, and Chrysophyllum albidum (Chapman et al., 1997).

\section{Sampling}

Fieldwork was conducted between May and August 1995 and from November 1996 through December 1997. Collections of amphibians and reptiles were made using a variety of techniques. At Kanyawara, the four amphibian breeding sites were surveyed twice weekly (nocturnal and diurnal) between 15 November 1996 and 1 December 1997, resulting in approximately 625 total hours of active searching in these habitats (Vonesh, unpubl. data). In addition, 340 leaf litter plots measuring $5 \times 5 \mathrm{~m}$ were sampled between March and November 1997 (Vonesh in press). Each plot was searched for at least 1 person-hr. Locations of the plots were randomly assigned within the forest using the Kanyawara trail grid map. At Kanyawara, these methods were supplemented by opportunistic searching, which was the primary sampling method at the other sites, unless otherwise noted above.

Snakes and lizards occurred at lower densities than most amphibians and were less frequently observed in the West African tropics than in comparable Neotropical forest habitats (Lawson, 1993). This is also true in Kibale, and opportunistic road cruising was the most reliable method for obtaining snake specimens. Most snakes collected in this manner were found between Kanyawara and Fort Portal or between Kanyawara and the Dura River site (Figure 1). The first route runs through tea plantation and farmbush habitats and the second runs through tea plantations, farmbush and forest.

In addition to specimens collected during this study, specimens were also collected by Drs. Colin and Lauren Chapman from 1990 to 1995. In total, approximately 500 specimens were collected from Kibale and neighboring areas. Collection of vouchers was limited by permit to three specimens per gender per locality within the national park boundaries; thus, many more individuals were observed than were collected. Specimens were preserved in the field with $10 \%$ buffered formalin and were 
subsequently transferred to $70 \%$ ethanol. Specimens are shared between the Makerere University Zoological Collection, Kampala, Uganda, and the California Academy of Sciences, San Francisco (Appendix A).

\section{Faunal Comparisons}

Herpetofaunal lists for the eight equatorial African sites compared in this study were compiled primarily from published lists (Table 1): Korup National Park, Cameroon (Lawson, 1993); Parc National des Virunga, DRC (Amphibians - Laurent, 1972; Reptiles - De Witte, 1941); Parc National de la Garamba, DRC (Amphibians- Inger, 1968; Reptiles - De Witte, 1966); Kibale National Park, Uganda (this study); BwindiImpenetrable National Park (Amphibians - Drewes and Vindum, 1991; Reptiles Drewes and Vindum, 1997); forest reserves in the eastern and western Usambara Mountains, northeastern Tanzania (Howell, 1993); Udzungwa National Park, Tanzania (Howell, 1993); and the Arabuko-Sokoke Forest Reserve of coastal Kenya (KIFCON, 1995).

These sites ranged from Korup in coastal West Africa at long $8^{\circ} 4^{\prime} \mathrm{E}$ to Arabuko in coastal Kenya at long $39^{\circ} 30^{\prime} \mathrm{E}$, and from Korup at lat $5^{\circ} \mathrm{N}$ to Udzungwa at lat $7^{\circ} 50^{\prime} \mathrm{S}$ (Figure 15). Several broad habitat categories are found among these sites. Korup and Virunga are composed primarily of Guinea-Congolean rain forest. Korup is mostly lowland rain forest ( $97 \%$ of the area is located below $850 \mathrm{~m}$ elevation) whereas the elevational range in Virunga extends from $710 \mathrm{~m}$ to over $5000 \mathrm{~m}$ in the Ruwenzori Mountains (Table 1). Garamba primarily consists of moist mixed woodlands and savanna, with gallery forests along larger streams and in deeply entrenched ravines (Inger, 1968). Both Kibale and Bwindi in western Uganda are situated upon the central African plateau between the western and eastern rift valleys. Both Tanzanian localities, the Usambara and the Udzungwa mountains, are characterized by mid-elevation to montane rain forest. Arabuko-Sokoke is comprised of relatively dry coastal forest. The combined species list of these sites includes 191 amphibian species (Appendix B), 10 turtle species , 98 lizard species, and 134 snake species (Appendix C). This represents roughly $55 \%$ of the total estimated amphibian fauna of African rain forests, and a higher proportion of African forest reptiles (Duellman, 1993).

The herpetofaunal inventory of each site was based on at least 3 mo of sampling, and most were sampled for considerably longer. Attempts were made to update genera and species names, particularly for older studies. Frost (1985) was followed for most amphibians; however, I followed Drewes (e.g., Drewes and Vindum 1991) in regarding arthroleptid frogs as a subfamily of Ranidae. I also retained the genus Hylarana in keeping with other African workers (e.g., Perret, 1977; Drewes and Vindum, 1991; Lawson, 1993). Reptile nomenclature follows Broadley and Howell (1993), Meirte (1992), Pitman (1974), and Hughes (1983, 1985).

Hierarchical cluster analysis was performed on the combined species lists for all eight sites to determine nearest-neighbor groupings based on the Bray-Curtis measure of similarity (Bray and Curtis, 1957). The Bray-Curtis index (BCl) has been shown to reflect true similarity more accurately than other measures (Bloom, 1981) and is 
commonly used in cluster analyses in biogeographical studies (e.g., Turpie et al., 2000; Mahon et al., 1998).

\section{RESULTS}

Herpetofaunal Inventory and Natural History

Fourteen amphibian species, 13 lizard species, and 15 snake species previously unknown from Kibale were collected and/or observed during this study. The resulting herpetofauna list consists of 29 amphibian species (Table 2), 15 lizard species , and 32 snake species (Table 3 ). In addition, one amphibian and six snakes are listed as expected for the park based on their presence in other nearby Ugandan forests.

All amphibians observed belonged to the order Anura (Table 2). Salamanders (Caudata) are not known from sub-Saharan Africa, and caecilians (Gymnophiona) have not been collected from Uganda. Among anurans, three aquatic species (11\% Kibale's amphibian fauna) were collected all belonging to the genus Xenopus; Xenopus wittei and Xenopus laevis victorianus were often found in sympatry. Xenopus vestitus is known from only one specimen, collected from the Dura River. The terrestrial leaf litter frog assemblage consists of nine species (32\% of Kibale's amphibian fauna) from three genera, Bufo, Phrynobatrachus, and Schoutedenella. The bufonids, Bufo funereus and Bufo kisoloensis were forest-dwelling, whereas Bufo maculatus was abundant in farmbush habitat. Five species of Phrynobatrachus are known from Kibale, but two are very rare. Phrynobatrachus dendrobates was collected in 1938 (Loveridge 1942b), but has not been collected since; and only one specimen of Phrynobatrachus $\underline{v e r s i c o l o r}$ has been collected from Kibale. Of the remaining three Phrynobatrachus, $\underline{P}$. graueri was the most commonly observed frog at most sites and was often found breeding syntopically with the smaller $\underline{P \text {. parvulus. Phrynobatrachus auritus was }}$ uncommon at Kanyawara but frequently observed at the Dura site. Hylarana albolabris and Rana angolensis were common both in and outside the forest in association with water bodies, and could best be classified as semiaquatic species (7\% of Kibale's amphibian fauna). Both Ptychadena species were associated with forest gaps, though $P$. mascareniensis appeared to be more strictly limited to the forest. Twelve arboreal or semi-arboreal frogs ( $43 \%$ of Kibale's amphibian fauna) of the genera Afrixalus, Leptopelis, Hyperolius, Phlyctimantis, and Chiromantis were collected or observed in the park. Schiøtz (1975) reported that 4 Hyperolius species, Leptopelis christyi, and Phlyctimantis verrucosus occur in Kibale. The new additions to the Kibale treefrog list include: Afrixalus laevis, known from a single specimen collected at Sebatoli; Hyperolius kuligae; Leptopelis kivuensis; and the rhacophorid, foam-nesting treefrog Chiromantis rufescens (M. Cherry, pers. com.). This is the second Ugandan record for $C$. rufescens, a central and West African species that reaches its eastern limit in both Budongo Forest Reserve and Kibale National Park in western Uganda.

Little is known about the feeding ecology of most of these frog species. Frogs typically prey upon invertebrates, but other taxa are sometimes taken (Table 2). Xenopus

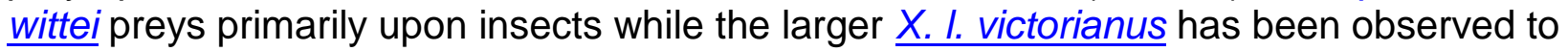


feed on insects, other frog larvae, and small fish (pers. obs.). The two forest bufonids and the Schoutedenella are active foragers that feed primarily on ants, Phrynobatrachus graueri primarily feeds on collembolans, and the treefrogs Leptopelis kivuensis and Hyperolius lateralis appear to be sit-and-wait predators on larger, softbodied insects (Vonesh 1998).

Five anuran reproductive modes occur in Kibale (Table 2). Most species $(61 \%$ of Kibale's amphibian fauna) deposit their eggs in water, and eggs hatch into aquatic larvae. Seven species (25\% of Kibale's amphibian fauna) from three genera (one Phrynobatrachus, two Afrixalus, four Hyperolius) deposit their eggs on vegetation above water, which subsequently hatch and drop into the water as aquatic larvae. The two Leptopelis (7\% of Kibale's amphibian fauna) species bury their eggs in the moist soil of depressions that later fill with water, and Chiromantis rufescens (4\% of Kibale's amphibian fauna) deposits eggs in arboreal foam nests from which aquatic larvae hatch. Only the arthroleptine Schoutedenella schubotzi has direct development (4\% of Kibale's amphibian fauna).

Lizards were uncommon within the forest (Table 3). The most abundant species were those associated with the forest edge or disturbed farmbush habitats (e.g., Hemidactylus mabouia, Agama (Stellio) atricollis, Mabuya straita, Chamaeleo ellioti). Within the forest, two the lacertids Adolfus africanus and Adolfus vauereselli were most conspicuous, actively foraging in the litter and basking in sun flecks. Of these two species, $A$. africanus appeared to be more arboreal. The highly arboreal lacertid Holaspis guentheri guentheri was captured once. Of the forest chameleons, Rhampholeon boulengeri was the most common species, and was usually observed in low shrubs. The other two forest chameleons, Chamaeleo adolfifriederici and Chamaeleo ituriensis, were uncommon to rare and appear to be more arboreal in their habits.

Of the 37 species of snakes that occur or are likely to occur in Kibale, $11 \%$ are fossorial or burrowing, $38 \%$ are primarily terrestrial, $51 \%$ are primarily arboreal, and less than $3 \%$ are primarily aquatic (Table 3 ). Most species are probably either nocturnal or active during both day and night. The general feeding ecology of Kibale's snakes can be determined from Pitman (1974), the stomach contents of specimens from the present study, and field observations. Of the 37 snake species, $8 \%$ feed on invertebrate prey, $8 \%$ feed on fish, $24 \%$ prey on lizards or other snakes, $51 \%$ prey on frogs, $37 \%$ feed on small mammals such as rodents, $14 \%$ feed on birds, and 5\% (Bitis gabonica, Python sebae) are capable of taking larger mammals as prey (categories add to more than $100 \%$ because many species prey on several taxa). Among the more specialized in diet are Dasypeltis atra, which feeds on bird eggs; Duberria lutrix, which preys on slugs; Causus lichtensteinii, which feeds on forest toads; and Thelotornis kirtlandii and Lycophidion ornatum, which feed on lizards.

Regional Comparisons 
Total species richness among the eight sites ranged from 167 species in Korup to 33 species in Udzungwa (Appendix B and Appendix C). The Kibale, Bwindi, and Virunga sites exhibit the greatest similarity among the eight sites (Figure 16 and Table 4). Kibale and Bwindi are separated by about $200 \mathrm{~km}$ along a north-south gradient in western Uganda. They share 20 species of amphibians and reptiles. Both sites show strong similarity to the Virunga site (23 and 24 shared species respectively), from which they are separated by less than $100 \mathrm{~km}$ (Table 4).

The herpetofauna of Korup in Cameroon is most similar to that of Virunga, $2300 \mathrm{~km}$ to the east, and least similar to the montane forests of Tanzania and the coastal forests of Kenya, over $3300 \mathrm{~km}$ distant (Figure 16 and Table 4). The Usambaras and Udzungwas are most similar to each other, and show very little similarity to any other sites (Figure $\underline{16}$ ). Among the 8 areas (Table 4), reptile faunas were slightly more similar (mean $\mathrm{BCl}=$ 0.19 ) than amphibian faunas (mean $\mathrm{BCl}=0.14$ ).

A comparison of mid-elevation and montane tropical rain forests from Africa, central America, and southeast Asia show that forest-dependent herpetofaunas of higher elevation sites comprise between 20 and 67 species (Table 5). Virunga National Park and Monteverde, Costa Rica (Timmerman 1981) supported the richest herpetofaunas among higher elevation sites; Kibale and Bwindi support an intermediate number of species; and Cuernos de Negros, Philippines (Brown and Alcala 1961) and the Tanzanian Udzungwa Mountains had the lowest species richness. Reptiles outnumbered amphibians at all sites except the Udzungwas and Korup (at Korup this is likely due to low sampling effort at higher elevations). Amphibian richness was greatest in Korup, and reptile richness was highest in Virunga.

\section{DISCUSSION}

The Kibale herpetofauna consists of two main assemblages: species that seem to be forest-dependent and those that do well in a variety of habitats, both inside and outside the forest. Because of the lack of ecological, physiological, and behavioral studies for African forest amphibians and reptiles, it is often difficult and somewhat subjective to decide which species are truly dependent upon forest habitat. This difficulty has been discussed with respect to a variety of amphibian and reptile taxa (e.g., Howell, 1993; Schiøtz, 1975; Hughes, 1983).

In Kibale, the herpetofaunal component not dependent on forest habitat, the farmbush component, is characterized by the frogs Xenopus laevis victorianus, Bufo maculatus, Schoutedenella schubotzi, $\underline{\text { Hylarana albolabris, } \text { Phrynobatrachus }}$ parvulus, Phrynobatrachus chrysogaster, $\underline{\text { Ptycadena mascareniensis, }} \underline{\text { Rana }}$ angolensis, Afrixalus quadravittatus, Hyperolius cinnamomeoventris, Hyperolius kivuensis, Hyperolius nasutus, and Hyperolius viridiflavus, which comprise roughly $46 \%$ of the frog fauna. Five lizards, Hemidactylus mabouia, Chamaeleo ellioti, Mabuya striata, Mabuya maculilabris, and Mabuya megalura are found primarily outside the forest, and two, Agama atricollis and Lygosoma fernandi, are edge species that were never observed in the forest interior. Of the remaining eight species, two were collected 
only from exotic pine plantations adjacent to the forest. Locality records for these, plus Cnemaspis quattuorseriata from Bwindi (Drewes and Vindum, 1997) and Leptosiaphos aloysiisabaudiae from Garamba (De Witte, 1966) and Uganda (Peracca, 1907), suggest that these species are not forest-dependent. Thus, approximately $60 \%$ of Kibale's lizard fauna should be considered part of the farmbush assemblage. Hughes (1983) reviewed the forest, farmbush, and savanna snake faunas of tropical Africa, and I follow his classification. Accordingly, of the 37 known and expected snakes in Kibale, 32\% (12) are common in both forest and savanna habitats. These are Atractaspis irregularis, Bitis gabonica, Crotaphopeltis hotamboeia, Duberria lutrix, Lycophidion ornatum, Lamprophis lineatus, Naja melanoleuca, Philothamnus angolensis, Psammophis phillipsii, Python sebae, Typhlops angolensis, and Typhlops punctatus. Philothamnus semivarigatus is considered a savanna form by Hughes (1983).

The transitional nature of Kibale between lowland and montane forest is evident in the herpetofauna. Among the forest-dependent species in Kibale there are elements of both a montane fauna, consisting primarily of species endemic to central Africa, and a lowland forest fauna that often ranges to West Africa. Wide-ranging species, characteristic of the lowland rain forest of the Guinea-Congolean forest include $14 \%$ of the frogs (Bufo funereus, Phrynobatrachus auritus, Afrixalus laevis and Chiromantis rufescens), $20 \%$ of the lizards (Lygosoma fernandi, Adolfus africanus, and Holoaspis guentheri guentheri) and $46 \%$ of the snakes (17 species, Table 3 ). The montane forestdependent species characteristic of central Africa (Laurent, 1974) make up $28 \%$ of the Kibale frog fauna (Xenopus wittei, Xenopus vestitus, Bufo kisoloensis, Phrynobatrachus dendrobates, Phrynobatrachus graueri, Phrynobatrachus versicolor, $\underline{\text { Phlyctimantis. }}$ verrucosus and Leptopelis kivuensis), $13 \%$ of the Kibale lizard fauna (Adolfus vauereselli, Chamaeleo adolfifriederici) and $9 \%$ of the Kibale snake fauna (Philothamnus heterodermus ruandae, Atheris nitchei, and Dasypeltis atra). The remaining species represent mid-and low-elevation forest forms that have distributions limited to central Africa. This category includes four frogs (Hyperolius lateralis, Hyperolius kuligae, Hyperolius kivuensis, and Leptopelis christyI) the Ituri chameleon, Chamaeleo ituriensis, and four snakes (Polemon christyi, Geodipsas depressiceps, Thrasops jacksonii, Dendroaspis jamesoni).

Clearly, the farmbush assemblage represents a significant proportion of the Kibale herpetofauna. In contrast, Bwindi, the site most similar to Kibale, is characterized by a higher proportion of forest-dependent species. At Bwindi, $70 \%$ of the frog species (versus 54\% at Kibale) are forest-dependent. This is largely due to the presence of five montane forest treefrog species and the montane endemic Rana ruwenzorica which do not occur in Kibale. The lizards show the same pattern: $50 \%$ of the species at Bwindi are forest-dependent (compared to $40 \%$ at Kibale), and again this is largely due to the presence of two endemic montane chameleons and two endemic montane skinks. Hamilton $(1976,1981)$ and Struhsaker (1981) hypothesized that Bwindi functioned as a forest refugium during the arid conditions of the last glacial maximum. Thus, the larger proportion of Albertine Rift endemic frogs and reptiles at Bwindi relative to Kibale is probably a function of its greater age and range in elevation. 
The zoogeography of tropical African forests is thought to be influenced by periods of forest expansion, associated with wet interglacial periods, and forest retraction, associated with colder drier conditions during periods of glaciation. Much attention has focused on the last glacial maximum, 18,000 years ago, when the extent of tropical forest was greatly reduced, creating the hypothesized isolated forest refugia (Hamilton, 1976; Moreau, 1966,1969). This vicariance promoted allopatric speciation in these refugia. Warmer, wetter conditions of the past 12,000 years have been associated with expansion of rain forests, which reached their maximum extent approximately 7,000 years ago and allowed mixing of previously isolated forest faunas. A number of authors have used modern patterns of distribution of forest species to elucidate past forest history, and have argued that patterns of richness and endemism suggest two principle core refugia, one in Cameroon and Gabon, and another in eastern Zaire, with smaller refugia in West Africa and coastal East Africa (Hamilton, 1976, 1992; Moreau, 1969).

Faunal comparisons among the eight sites examined here are generally consistent with forest refugia theory. The high richness of Korup National Park and Virunga National Park is consistent with hypothesized core refugia (Hamilton, 1988), though lack of distribution data from intervening areas precludes finer scale examination of potential gradients of declining diversity between these areas (Hamilton, 1988). Kibale, Bwindi, and Virunga are more similar to each other than to the fauna of West Africa, represented by Korup (Figure 16). This is consistent with the hypothesis that these areas have been connected more frequently or over a longer time period. Schiøtz (1976) suggested that the forests of Uganda and western Kenya are depauperate outliers of Virunga, the eastern Congo core area. The lower total richness observed in Kibale and Bwindi is probably a function of both their smaller size and their higher elevation with corresponding loss of many lowland rain forest forms present on the Congo side of the Albertine Rift. However, when the number of species per area is considered, both Kibale and Bwindi exhibit higher values then Virunga National Park In fact, the smaller parks consistently exhibited higher species per area values. This may be correlated with habitat degradation and illustrates the importance of conserving these remaining forests. These forests are now small "islands," but they may have maintained many of the species that were present when they were part of larger, continuous forest.

The montane forests of Tanzania are believed to represent a minor refugium that has been isolated from the Congo forest block for millions of years, a conclusion supported by the high endemism of many taxa in these forests. In the Usambara Mountains, $87 \%$ of the amphibians and $55 \%$ of the reptiles are endemic to Tanzanian montane rain forest (Howell, 1993). Faunal comparisons with Kibale also suggest a long isolation period. The Kibale herpetofauna is much more similar to Korup, $2420 \mathrm{~km}$ distant, than to the Usambaras, $1050 \mathrm{~km}$ away; and there is no overlap between the Udzungwa fauna and any site except Usambara. These results also demonstrate the uniqueness of the coastal dry forest fauna, represented by the Arabuko-Sokoke site. Coastal forest is one of the most imperiled African habitats and is home to a distinctive herpetofauna unlike that of the wetter tropical forest. 


\section{Conclusions}

Kibale forest supports a rich herpetofauna of more than 70 species, belonging to two primary faunal elements: farmbush species and the forest-dependent species. The relatively high number of species observed is probably related to the heterogeneous habitat of forest, swamp, grassland, and agricultural areas characteristic of Kibale. Despite the large number of farmbush species, the number of forest-dependent species in Kibale is comparable to that of other mid-elevation forests in Africa, Central America, and the Philippines. None of these species is endemic to Kibale, and only a few are restricted to the Albertine Rift. Most of the endemic amphibian and reptile species of the Albertine Rift are characteristic of higher elevation montane forest, which is not present at Kibale. Previous researchers have noted that the forest herpetofaunas of East Africa consist of two nonoverlapping groups. One group represents the extension of the Guinea-Congolean rain forest fauna, and the second is largely endemic to the coastal mountains of Tanzania. The Kibale herpetofauna is clearly an example of the first group, as suggested by the high species overlap with both the Parc National des Virunga in eastern Congo-Zaire and secondarily to Korup National Park in Cameroon. The high similarity among Virunga, Bwindi, and Kibale relative to the similarity of these forests to the forests of West and East Africa is consistent with the hypothesized existence of core forest refugia in eastern Zaire.

\section{ACKNOWLEDGMENTS}

Thanks to L. J. Chapman, C. A. Chapman, H. B. Lillywhite, and S. R. Balcomb for their support during the field work, R. C. Drewes, and Jens Vindum for assistance in species identification, and N. Seavy, and S. R. Balcomb who provided comments on an early draft. I would also like to thank the staff at MUBFS, Uganda Wildlife Authority and the Department of Herpetology at the California Academy of Sciences. This research was supported in part by the Chicago Zoological Society, Brooksfield Zoo and the Charles Stearns Grant of the California Academy of Sciences. This study was conducted with the permission of the Uganda National Council for Science and Technology (Permit \#EC308).

\section{LITERATURE CITED}

ARNOLD, E. N.

1989. Systematics and adaptive radiation of equatorial African lizards assigned to the genera Adolfus, Bedriagaia, Gastropholis, Holaspis, and Lacerta (Reptilia: Lacertidae). Journal of Natural History 23: 525-555.

BLOOM, S. A.

1981. Similarity indices in community studies: Potential pitfalls. Marine Ecology Progress Series 5: 125-128. 
BAUER, A. M.

1993. African-South American relationships: A perspective from the Reptilia. Pages 245-288 in Biological Relationships Between Africa and South America (P. Goldblatt ed). Yale University Press, New Haven, Connecticut.

BRAY, J. R., AND J. T. CURTIS.

1957. An ordination of the upland forest communities of southern Wisconsin. Ecological Monographs 27(4): 325-349.

BROADLEY, D. G. AND K. M. HOWELL.

1991. A checklist of the reptiles of Tanzania, with synoptic keys. Syntarsus 1: 1-70.

BROWN, W. C. AND A. C. ALCALA.

1961. Populations of amphibians and reptiles in submontane and montane forests of Cuernos de Negros, Philippine Islands. Ecology 21: 297-308.

CHAPMAN, C. A., L. J. CHAPMAN, R. WRANGHAM, G. ISABIRYE-BASTUTA, AND K. BEN-DAVID.

1997. Spatial and temporal variability in structure of a tropical forest. African Journal of Ecology 35: 287-302.

COLLINS, N. M.

1992. Introduction. Pages 6-16 in The Conservation Atlas of Tropical Forests in Africa (J. Sayer, C. Harcourt, and M. Collins, eds). Macmillan Publishers, Ltd., Basingstoke, England.

DEWITTE, G. F.

1941. Batraciens et Reptiles. Exploration du Parc National Albert, Mission G. F. De Witte (1933-1935). Fascicle 33. Institut des Parcs Nationaux du Congo Belge, Bruxelles. 1966. Reptiles. Exploration du Parc National de la Garamba, Mission H. De Saeger (1949-1952). Fascicle 48. Institut des Parcs Nationaux du Congo Belge, Bruxelles.

DREWES, R. C.

1997. A new species of treefrog from the Serengeti National Park, Tanzania (Anura: Hyperoliidae: Hyperolius). Proceedings of the California Academy of Sciences, 49: 439446. 
AND J. V. VINDUM..

1991. Amphibians of the Impenetrable Forest, southwest Uganda. Journal of African Zoology 108: 55-70.

1997. Amphibians and reptiles of Bwindi-Impenetrable National Park. Unpublished report to the Uganda Wildlife Authority.

DUELLMAN, W. E.

1993. Amphibians in Africa and South America: Evolutionary history and ecological comparisons. Pages 200-243 in Biological Relationships Between Africa and South America (P. Goldblatt, ed). Yale University Press, New Haven, Connecticut.

FROST, D. R.

1985. Amphibian Species of the World: A Taxonomic and Geographic Reference. Allen Press, Inc. and The Association of Systematic Collections, Lawrence, Kansas, USA.

HAMILTON, A. C.

1976. The significance of patterns of distribution shown by forest plants and animals in tropical Africa for the reconstruction of Upper Pleistocene palaeoenvironments: A review. Palaeoecology Africa 9: 63-97.

1981. The Quaternary history of African forests: Its relevance to conservation. African Journal of Ecology 19:1-6.

1988. Guenon evolution and forest history. Pages 13-34 in A Primate Radiation:

Evolutionary Biology of the African Guenons (Gautier-Hion, A. et al., eds). Cambridge University Press, Cambridge.

1992. History of forests and climate. Pages 17-25 in The Conservation Atlas of Tropical Forests Africa (J. Sayer, C. Harcourt, and N. Collins, eds). Macmillan Publishers Ltd., Basingstoke.

HOWELLI, K. M.

1993. Herpetofauna of the East African forests. Pages 173-201 in Biogeography and Ecology of the Rain Forests of Eastern Africa (J. C. Lovett and S. Wasser, eds). Cambridge University Press, New York.

HUGHES, B.

1983. African snake faunas. Bonner Zoologische Beitrage. 34: 311-356.

1985. Progress on a taxonomic revision of the African green tree snakes (Philothamnus spp.). Pages 511-530 in Proceedings of the International Symposium of African Vertebrates (K. L. Schuchmann, ed). Bonn, Germany.

INGER, R. F. 
1968. Amphibia. Exploration du Parc National de la Garamba, Mission H. Saeger, Fascicle 52. Institut des Parcs Nationaux du Republique Democratique du Congo, Kinshasa.

\section{KENYA INDIGENOUS FOREST CONSERVATION PROGRAMME (KIFCON)}

1995. Arabuko Sokoke Forest and Mida Creek: The official guide. Majestic Printing Works Ltd., Nairobi, Kenya.

\section{LAURENT, R. F.}

1972. Amphibiens. Exploration du Parc National des Virungas. Fascicule 22. Recherches Enterprises par l'Institut National pour la Conservation de la Nature de la Republique du Zaire, Bruxelles.

1974. About the herpetofauna of central African montane forest. Pages 350-358 in Advances in Herpetology and Evolutionary Biology: essays in honor of Ernest $\mathrm{E}$. Williams (Anders G.J. Rhodin and K. Miyata, eds). Museum of Comparative Zoology, Cambridge, Mass.

LAWSON, D. P.

1993. The reptiles and amphibians of the Korup National Park project, Cameroon. Herpetological Natural History 1: 27-90.

\section{LOVERIDGE, A.}

1935. Scientific results of an expedition to rain forest regions in Eastern Africa. I. New reptiles and amphibians from East Africa. Bulletin of the Museum of Comparative Zoology 79: 3-19.

1942a. Scientific results of a fourth expedition to forested areas in East and Central Africa. IV. Reptiles. Bulletin of the Museum of Comparative Zoology 91: 237-373. $1942 b$. Scientific results of a fourth expedition to forested areas in East and Central Africa. V. Amphibians. Bulletin of the Museum of Comparative Zoology 91: 377-436. 1942c. Scientific results of a fourth expedition to forested areas in East and Central Africa. VI. Itinerary and Comments. Bulletin of the Museum of Comparative Zoology 91: 191-203.

1957. Checklist of the reptiles and amphibians of East Africa (Uganda, Kenya, Tanzania, and Zanzibar). Bulletin of the Museum of Comparative Zoology 117: 153362.

MAHON, R., S. K. BROWN, K. C. T. ZWANENBURG, D. B. ATKINSON, K. R. BUJA, L. CLAFIN, G. D. HOWELL, M. E. MONACO, R. N. O'BOYLE, AND M. SINCLAIR.

1998. Assemblages and biogeography of demersal fishes of the east coast of North America. Canadian Journal of Fisheries and Aquatic Sciences 55 (7): 1704-1738. 
MEIRTE, D.

1992. Cles de determination des serpentes d'Afrique. Annales Sciences Zoologiques, Musee Royalde l' Afrique Centrale, Tervuren, Belgique 267: 1-152.

MITTERMEIR, R. A., J. CARR, I. SWINGLAND, T. WERNER, AND R. MAST.

1992. Conservation of amphibians and reptiles. Pages 59-80 in Herpetology: Current Research on the Biology of Amphibians and Reptiles. Proceedings of the First World Congress of Herpetology, Prague.

MOREAU, R. E.

1966. The Bird Faunas of Africa and its Islands. Academic press, London, England. 1969. Climatic changes and the distribution of forest vertebrates in West Africa. Journal of Zoology 158: 39-61.

NEWMARK, W. D.

1998. Forest area, fragmentation, and loss in the Eastern Arc Mountains: Implications for the conservation of biological diversity. Journal of East African Natural History 87: 18.

PERACCA, N. G.

1907. Spedizione al Ruwenzori di S. A. Luigi Amedeo di Savoia Duca degli Abruzzi Nuovi. Rettilli ed Amfibi; diagnosi preventive. Bolletino dei Musei di Zoologia ed Anatomia Comparata della Università di Torino. 22: 1-3.

PERRET, J.-L.

1977. Les Hylarana (Amphibiens, Ranides) du Cameroon. Revue Suisse Zoologie 84: 841-868.

PITMAN, R. S.

1974. A Guide to the Snakes of Uganda. Wheldon and Wesley, Ltd, Glasgow, Great Britain.

SCHIØTZ, A.

1975. The Treefrogs of eastern Africa. Steenstrupia, Copenhagen.

1976. Zoogeographical patterns in the distribution of East African treefrogs (Anura:

Ranidae). Zoologica Africana 11(2): 335-338.

SKORUPA, J. P. 
1988. The Effect of Selective Timber Harvesting on Rain Forest Primates in Kibale Forest, Uganda. Ph.D. Dissertation, University of California, Davis, California.

STRUHSAKER, T. T.

1981. Forest and primate conservation in East Africa. African Journal of Ecology 19: 99114.

1997. Ecology of an African rain forest. University of Florida Press, Gainesville, Florida, USA.

THE WORLD RESOURCES INSTITUTE

1994. World Resources 1994-1995. Oxford University Press, New York.

TIMMERMAN, W. W.

1981. The Reptiles and Amphibians of Monteverde, Costa Rica: An Annotated Checklist to the Herpetofauna of Monteverde. Tropical Science Center, San Jose, Costa Rica.

TURPIE, J. K., L. E. BECKLEY, AND S. M. KATUA.

2000. Biogeography and the selection of priority areas for conservation of South African coastal fishes. Biological Conservation 92: 59-72.

VONESH, J. R.

1998. The Amphibians and Reptiles of Kibale Forest, Uganda: Herpetofaunal Survey and Ecological Study of the Forest Floor Litter Community. [M.Sc. thesis], Department of Zoology, University of Florida, Gainesville, Florida.

In press. Patterns of richness and abundance in a tropical African leaf litter herpetofauna. Biotropica. 